\title{
Pengaruh Pemberian Asam Amino Metionin-Sistin pada Pakan yang Terkontaminasi Aflatoxin B1 Terhadap Mortalitas dan Kinerja Organ Dalam Ayam Broiler
}

\author{
Listya Purnamasari ${ }^{1}$, Ali Agus $^{2, a}$, Cuk Tri Noviandi ${ }^{2}$ \\ ${ }^{1}$ Program Studi Peternakan, Fakultas Pertanian, Universitas Jember, Jl Kalimantan no. 37, Jember 68121, \\ Jawa Timur, Indonesia \\ ${ }^{2}$ Program Studi Industri Peternakan, Fakultas Peternakan, Universitas Gadjah Mada, Jl Fauna no.3, \\ Yogyakarta 55281, DI Yogyakarta, Indonesia \\ aemail: ali.agus@ugm.ac.id
}

\begin{abstract}
Abstrak
Kondisi iklim di Indonesia dengan suhu dan kelembapan yang tinggi merupakan kondisi optimal bagi perkembangan jamur Aspergillus flavus penghasil toksin aflatoksin. Aflatoksin dapat menurunkan produktivitas ternak. Penelitian ini bertujuan untuk mengetahui efek penambahan asam amino metionin-sistin untuk menurunkan efek toksin dari aflatoksin B1 (AFB1) pada pakan ayam broiler terhadap mortalitas dan kinerja organ dalam ayam broiler. Sebanyak 240 ekor ayam broiler mixed sex diteliti dengan 9 macam perlakuan dengan pola rancangan faktorial $3 \times 3$ dengan faktor kadar asam amino metionin-sistin (75,100, dan 125\%) dan kadar AFB1 (0, 200, dan 400 $\mathrm{ppb}$ ). Variabel yang diamati adalah bobot karkas, mortalitas, bobot hati dan bobot bursa fabrisius. Hasil penelitian menunjukkan interaksi tidak terjadi bobot relatif hati, bobot relatif bursa fabrisius, bobot relatif karkas. Mortalitas tertinggi terjadi pada perlakuan T3 $(\mathrm{M}+\mathrm{C} 125 \%$ dan AFB1 0 ppb). Kombinasi pemberian asam amino metionin-sistin sebesar 75, 100, dan 125\% serta AFB1 0, 200 dan 400 ppb yang dikonsumsi ayam broiler, belum mampu memperbaiki kinerja organ dalam ayam broiler.
\end{abstract}

Kata kunci: Aflatoksin B1, Ayam broiler, Detoksifikasi, Metionin-sistin

Effects of Methionine-Cystine Amino Acid Supplementations in The Aflatoxin B1 Contaminated Broiler Diets on Mortality and Relative Internal Organ Weights

\begin{abstract}
The climatic conditions in Indonesia with high temperature and humidity are optimal conditions for Aspergillus flavus which produces aflatoxin as secondary metabolite. Aflatoxin can reduce livestock productivity. This research was aimed to observe the interaction of adding methioninecystine amino acid to decrease the effect of aflatoxin B1 (AFB1) from broiler chicken diet on performance production. A number of 240 mixed sex broiler chickens were treated in 9 treatments by factorial design $3 \times 3$ with methionine-cystine amino acid $(M+C)(75,100$, dan 125\%) factors and AFB1 levels $(0,200$, dan $400 \mathrm{ppb})$. The variables observed were carcass weight, mortality, liver weight and bursa fabricius weight. The results showed that the interaction did not occur in the relative weight of the liver, the relative weight of the bursa fabricius, the relative weight of the carcass. The highest mortality was occurred in the treatment $M+C 125 \%$ and AFB1 0 ppb. The combination of amino acid methionine-cystine administration of 75, 100, and 125\% and AFB1 0, 200 and 400 ppb consumed by broilers, has not been able to improve the performance of organs in broilers.
\end{abstract}

Keywords: Aflatoxin B1, Broiler chicken, Detoxification, Methionine-cystine. 


\section{Pendahuluan}

Laju pertumbuhan penduduk Indonesia diperkirakan akan terus meningkat tiap tahunnya yaitu sebanyak 238,5 juta jiwa pada tahun 2010 dan semakin meningkat menjadi 252,2 juta jiwa pada tahun 2014 (BPS, 2015). Peningkatan jumlah yang cukup besar ini berdampak pada pemenuhan protein, terutama protein hewani. Menurut Dirjen Peternakan (2015) produksi daging terbesar disumbang oleh ayam ras pedaging sebesar $51,97 \%$ pada tahun 2013 dan meningkat sebesar $52,79 \%$ pada tahun 2014.Faktor penting yang perlu diperhatikan dalam peningkatan produktivitas ternak adalah faktor pakan. Pakan yang tersedia harus mampu memenuhi kebutuhan nutrisi ternak baik dari segi kualitas dan kuantitas serta aman dikonsumsi. Bahan pakan unggas umumnya berasal dari biji-bijian seperti jagung. Kondisi Indonesia yang beriklim tropis dengan suhu dan kelembapan yang tinggi akan mempercepat terjadinya penurunan kualitas bahan baku pakan dan pertumbuhan kapang selama penyimpanan. Penyimpanan dengan kadar air yang tinggi juga akan menunjang pertumbuhan kapang, khususnya Aspergillus flavus dan $A$. parasiticus, yang akan menghasilkan metabolit sekunder berupa aflatoksin yang dapat mempercepat proses kerusakan bahan pakan.Aflatoksin B1 (AFB1) merupakan mikotoksin yang paling patogen dan bersifat karsinogenik serta dapat mempengaruhi kesehatan ternak, yaitu menimbulkan aflatoksikosis sehingga dapat menghambat produksi ternak. Selain itu, ternak yang mengkonsumsi pakan terkontaminasi AFB1 akan meninggalkan residu aflatoksin pada produk turunannya sehingga bila dikonsumsi oleh manusia akan berdampak negatif bagi kesehatan. Kandungan AFB1 dengan kadar rendah dan dikonsumsi dalam waktu yang lama, akan menyebabkan terjadinya kerusakan hati atau karsinoma hati primer. Selain itu, aflatoksikosis juga dapat menyebabkan kegagalan vaksinasi, berpengaruh terhadap penurunan produksi enzim empedu sehingga mengakibatkan turunnya daya cerna lemak yang berimplikasi pada menurunnya efisiensi ransum, produktivitas yang rendah dan anoreksia (Lesson dan Summers, 2005).
Oleh karena itu pengaruh aflatoksin tidak dapat dianggap remeh, karena menimbulkan kerugian atau kerusakan baik pada ternak maupun manusia. Menurut SNI, level aflatoksin yang dapat ditoleransi dalam pakan yaitu 50 ppb (BSN, 1998).Penurunan aflatoksin dalam ransum ternak telah diteliti sebelumnya oleh Utami (2009) dengan menggunakn ekstrak bawang putih dan Sadeghi et al. (2014) dengan menggunakan Savory Essential Oil. Penelitian ini diarahkan untuk mengetahui efektivitas pemberian asam amino metionin-sistin dalam pakan untuk menurunkan efek toksik AFB1 pada saluran pencernaan ayam broiler. Asam amino metionin sistein merupakan asam amino yang mengandung sulfur sebagai precursor gluthathion (yglutamycysteinglycine), yang berperan penting dalam eliminasi toksin melalui reaksi konjugasi yang berlangsung di hati dan diubah menjadi bentuk non-toksik yang dapat disekresikan. Tujuan dari penelitian ini yaitu Melihat dampak suplementasi terhadap mortalitas dan kinerja organ dalam ayam broiler yang mengkonsumsi pakan yang terkontaminasi AFB1.

\section{Materi Dan Metode}

Penelitian diawali dengan kontaminasi jagung menggunakan jamur Aspergillus flavus penghasil aflatoksin sebagai bahan baku pembuatan ransum ternak yang dilaksanakan di Laboratorium Teknik Hasil dan Ikutan Limbah, Fakultas Peternakan UGM. Penelitian kedua yaitu pemeliharaan ayam broiler di Laboratorium Ilmu Ternak Unggas Fakultas Peternakan UGM pada bulan Oktober 2015.

\section{Kontaminasi jagung}

Jagung yang digunakan dalam pakan dikontaminasi dengan jamur Aspergillus flavus dengan menggunakan Isolat koleksi PAU UGM dengan kode FNCC 6122 dan FNCC 6109 serta dari SEAMEO BIOTROP Bogor dengan kode BIO 2237 dan BIO 2236. Keempat Isolat kemudian ditumbuhkan dalam media jagung yang akan digunakan dalam formulasi pakan selama 10 - 15 hari pada suhu $25^{\circ} \mathrm{C}$. Pengujian selanjutnya dilakukan dengan metode Elisa menggunakan Maxsignal $^{\mathbb{B}}$ Total Aflatoxin 
Elisa Kit BIO Scientific (Purnamasari, et al., 2016).

\section{Pemeliharaan ayam}

Ayam yang digunakan yaitu ayam broiler Lohmann MB 202 platinum sebanyak 240 ekor yang sudah divaksinasi Newcastle Desease (ND) live, IB-ND killed dan IBD Transmune. Pakan yang digunakan tersaji dalam Tabel 1. Kandang yang digunakan yaitu kandang open house dengan cages sebanyak 40 buah. Komposisi pakan dan kandungan nutrien pakan dapat dilihat pada Tabel 1 dan hasil uji proksimat pakan dapat dilihat pada Tabel 2. Pemeliharaan dilaksanakan di kandang Laboratorium Ilmu Ternak Unggas, Fakultas peternakan UGM. Sebanyak 240 ekor ayam dikelompokkan dalam 9 perlakuan. Masing masing perlakuan terdiri dari 5 ulangan dan setiap ulangan terdapat 6 ekor ayam. Perlakuan pakan yang diberikan adalah:

$\mathrm{T} 1=\operatorname{ransum}(\mathrm{M}+\mathrm{C}) 75 \%+\mathrm{AFB} 10 \mathrm{ppb}$

$\mathrm{T} 2=$ ransum $(\mathrm{M}+\mathrm{C}) 100 \%($ normal $)+$

AFB1 $0 \mathrm{ppb}$

$\mathrm{T} 3=\operatorname{ransum}(\mathrm{M}+\mathrm{C}) 125 \%+\mathrm{AFB} 10 \mathrm{ppb}$

$\mathrm{T} 4=$ ransum $(\mathrm{M}+\mathrm{C}) 75 \%+\mathrm{AFB} 1200 \mathrm{ppb}$

$\mathrm{T} 5=$ ransum $(\mathrm{M}+\mathrm{C}) 100 \%($ normal $)+$

AFB1 $200 \mathrm{ppb}$

$\mathrm{T} 6=\operatorname{ransum}(\mathrm{M}+\mathrm{C}) 125 \%+\mathrm{AFB} 1200$

$\mathrm{ppb}$

$\mathrm{T} 7=\operatorname{ransum}(\mathrm{M}+\mathrm{C}) 75 \%+\mathrm{AFB} 1400 \mathrm{ppb}$
$\mathrm{T} 8=\operatorname{ransum}(\mathrm{M}+\mathrm{C}) 100 \%$ (normal) +

AFB1 $400 \mathrm{ppb}$

$\mathrm{T} 9=$ ransum $(\mathrm{M}+\mathrm{C}) 125 \%+\mathrm{AFB} 1400$

ppb

Ayam dipelihara sampai berumur 21 hari.

Perlakuan dimulai dari DOC (0-21 hari).

Pakan dan air minum diberikan secara $a d$ libitum. Kandang terbuat dari besi dalam bentuk cages/wire dilakukan pembersihan dan fumigasi dengan formalin $4 \%$ sebelum digunakan.

\section{Pengambilan data}

Pemeliharaan dan perlakuan pakan dilaksanakan dari umur 0-21 hari. Hasil kinerja organ dalam yang diukur yaitu bobot hati, bobot bursa, bobot karkas diambil pada saat ayam berumur 7,14, dan 21 hari. Mortalitas dihitung secara kumulatif hingga akhir pemeliharaan.

\section{Analisis data}

Pola rancangan yang digunakan adalah rancangan faktorial $3 \times 3$ dengan faktor kadar aflatoksin $(0,200,400 \mathrm{ppb})$ dan faktor kadar $\mathrm{M}+\mathrm{C}(75 \%, 100 \%, 125 \%)$. Data diolah dengan analisis ragam Analysis of variance atau ANOVA dengan menggunakan software SPSS kemudian dilanjutkan dengan uji Duncan multiple range test (DMRT). 
Tabel 1. Komposisi pakan basal pada penambahan $\mathrm{M}+\mathrm{C} 75 \%$ dan $\mathrm{M}+\mathrm{C} 125 \%$

\begin{tabular}{|c|c|c|}
\hline \multirow[t]{2}{*}{ Bahan baku } & Penambahan $\mathrm{M}+\mathrm{C} 75 \%$ & $\begin{array}{c}\text { Penambahan } \mathrm{M}+\mathrm{C} \\
125 \%\end{array}$ \\
\hline & Persentase $(\%)$ & Persentase $(\%)$ \\
\hline Jagung & 57,70 & 57,70 \\
\hline Soybean meal (SBM) & 34,69 & 34,69 \\
\hline Palm olein & 2,90 & 2,90 \\
\hline Dicalsium phospat & 1,35 & 1,35 \\
\hline Choline & 0,005 & 0,005 \\
\hline DL-methionine & 0,044 & 0,515 \\
\hline Premix $*$ & 0,21 & 0,21 \\
\hline Garam & 0,36 & 0,36 \\
\hline L-lysin $\mathrm{HCl}$ & 0,20 & 0,20 \\
\hline L-threonine & 0,07 & 0,07 \\
\hline Tepung tulang & 2,00 & 2,00 \\
\hline Pasir & 0,471 & 0 \\
\hline Total & 100 & 100 \\
\hline \multicolumn{3}{|c|}{ Perhitungan kandungan nutrien pakan } \\
\hline $\operatorname{ME}(\mathrm{kcal} / \mathrm{kg})$ & 3014,81 & 3014,81 \\
\hline PK $(\%)$ & 21,77 & 22,04 \\
\hline Ile $(\%)$ & 0,90 & 0,90 \\
\hline Lys (\%) & 1,27 & 1,27 \\
\hline Met $(\%)$ & 0,36 & 0,83 \\
\hline Cys (\%) & 0,35 & 0,35 \\
\hline TSAA $(\%)$ & 0,71 & 1,18 \\
\hline $\operatorname{Thr}(\%)$ & 0,86 & 0,87 \\
\hline $\operatorname{Trp}(\%)$ & 0,22 & 0,22 \\
\hline Val (\%) & 0,91 & 0,91 \\
\hline $\mathrm{Ca}(\%)$ & 0,95 & 0,95 \\
\hline $\mathrm{P}$ total $(\%)$ & 0,76 & 0,76 \\
\hline K (\%) & 0,87 & 0,87 \\
\hline $\mathrm{Cl}(\%)$ & 0,30 & 0,30 \\
\hline $\mathrm{Na}(\%)$ & 0,19 & 0,19 \\
\hline $\mathrm{Zn}(\mathrm{ppm})$ & 85,61 & 85,73 \\
\hline
\end{tabular}

*Campuran vitamin, cocksidiostat, asam amino sintetis, mineral dan growth promotor. Keterangan : ME= Metabolik Energi, $\mathrm{PK}=$ Protein Kasar, $\mathrm{Ca}=$ Kalsium, $\mathrm{K}=$ Kalium, $\mathrm{Cl}=\mathrm{Klorin}, \mathrm{Na}=\mathrm{Natrium}, \mathrm{Zn}=\mathrm{Zink}$.

Tabel 2. Hasil uji proksimat pakan** (\%)

\begin{tabular}{cccccc}
\hline \hline \multirow{2}{*}{ Perlakuan } & KA & LK & PK & SK & Abu \\
\hline T1 & 8,90 & 5,95 & 21,76 & 2,77 & 6,06 \\
T3 & 9,04 & 6,03 & 21,94 & 2,92 & 6,07 \\
T7 & 9,04 & 4,54 & 21,53 & 2,88 & 5,86 \\
T9 & 9,02 & 4,51 & 21,22 & 2,95 & 5,99 \\
\hline
\end{tabular}

Keterangan : $\quad \mathrm{LK}=$ Lemak Kasar, $\mathrm{KA}=$ Kadar Air, PK= Protein Kasar, SK= Serat Kasar **Hasil analisis dilakukan di Laboratorium Ilmu dan Teknologi Pakan, Fakultas Peternakan, Institut Pertanian Bogor. 


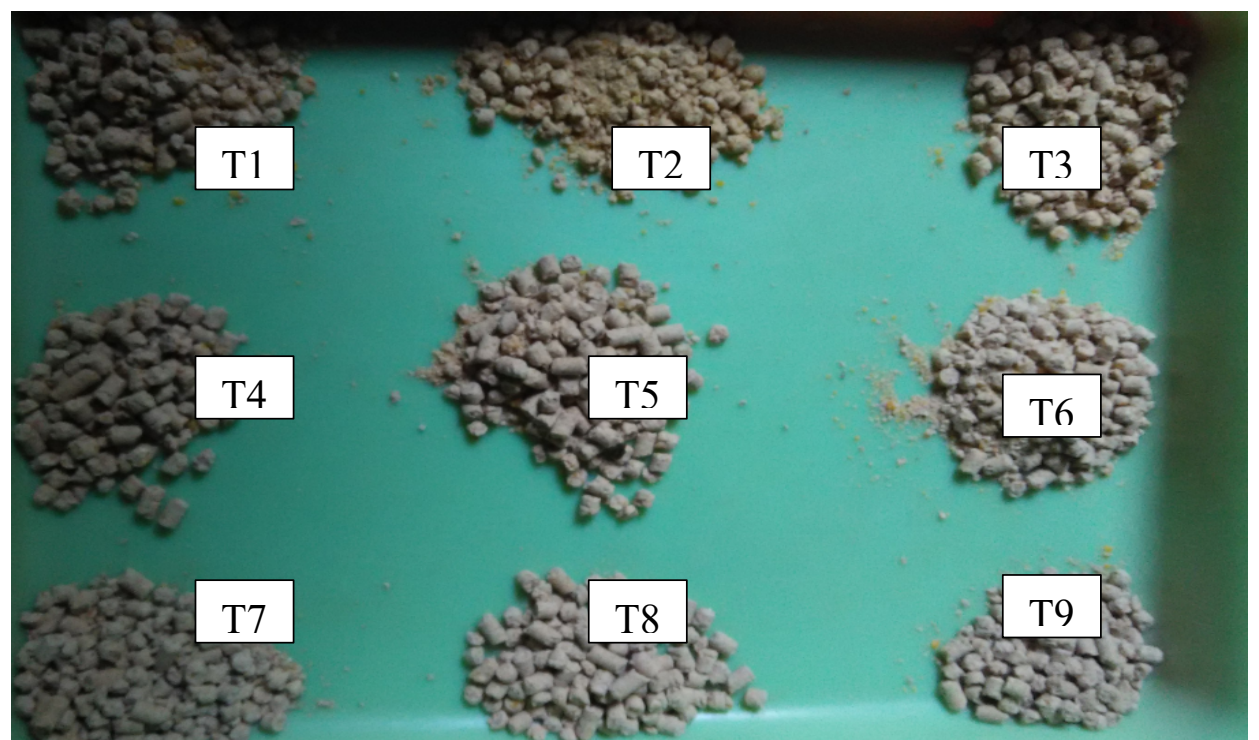

Gambar 1. Bentuk dan warna pakan pada setiap perlakuan

\section{Hasil Dan Pembahasan}

Efek interaksi antara $\mathrm{M}+\mathrm{C}$ dan $\mathrm{AFB} 1$ tidak terlihat pada parameter bobot relatif karkas, bobot relative hati dan bobot relative bursa fabrisius. Mortalitas tertinggi terjadi pada perlakuan $\mathrm{T} 3(\mathrm{M}+\mathrm{C} 125 \%$ dan AFB1 0 $\mathrm{ppb).}$

\section{Bobot relatif karkas dan mortalitas}

Data bobot karkas diperoleh pada hari ke-14 dan 21 dengan melakukan penyembelihan dan penghilangan bulu, organ dalam, kepala, dan kaki ayam. Bobot relatif karkas dihitung dengan pembagian antara bobot karkas dengan bobot hidup dikali dengan $100 \%$. Penggunaan bobot relatif ini disebabkan ayam yang disembelih memiliki bobot hidup awal yang berbeda- beda sesuai dengan nilai tengah masingmasing perlakuan. Bobot relatif karkas ayam (\%) pada umur 14 dan 21 hari tersaji pada Tabel 3. Hasil analisis pola faktorial menunjukkan bahwa efek interaksi antara $\mathrm{M}+\mathrm{C}$ dengan AFB1 terhadap bobot relatif karkas ayam pada penelitian ini tidak signifikan pada semua kelompok umur.

Bobot karkas ayam pada semua kelompok umur dalam penelitian ini tidak menunjukkan adanya efek yang nyata akibat perbedaan kadar $\mathrm{M}+\mathrm{C}$ dan $\mathrm{AFB} 1$. Hal ini disebabkan karena FCR pada penelitian ini juga tidak berbeda nyata (Purnamasari, et. al., 2019). Efisiensi jumlah pakan yang dikonsumsi menghasilkan bobot badan yang sama dan menghasilkan karkas sesuai

Tabel 3. Bobot relatif karkas ayam pada umur 14 dan 21 hari (\%)

\begin{tabular}{|c|c|c|c|c|}
\hline \multirow{2}{*}{ AFB1 } & \multicolumn{4}{|c|}{$\mathrm{M}+\mathrm{C}$} \\
\hline & $75 \%$ & $100 \%$ & $125 \%$ & Rerata \\
\hline \multicolumn{5}{|l|}{$\begin{array}{l}\text { Umur } 14 \\
\text { hari }\end{array}$} \\
\hline $0 \mathrm{ppb}$ & $68,79 \pm 0,55$ & $68,46 \pm 3,78$ & $69,04 \pm 3,84$ & $68,76 \pm 2,72$ \\
\hline $200 \mathrm{ppb}$ & $68,78 \pm 3,30$ & $67,94 \pm 1,33$ & $68,17 \pm 1,24$ & $68,29 \pm 1,92$ \\
\hline $400 \mathrm{ppb}$ & $70,26 \pm 1,15$ & $71,27 \pm 1,27$ & $68,12 \pm 1,06$ & $69,88 \pm 1,72$ \\
\hline $\begin{array}{l}\text { Rerata } \\
\text { Umur } 21 \\
\text { hari }\end{array}$ & $69,28 \pm 1,92$ & $69,22 \pm 2,62$ & $68,44 \pm 2,13$ & \\
\hline $0 \mathrm{ppb}$ & $73,32 \pm 1,67$ & $72,46 \pm 0,20$ & $72,38 \pm 1,84$ & $72,72 \pm 1,32$ \\
\hline $200 \mathrm{ppb}$ & $70,75 \pm 3,38$ & $72,75 \pm 4,36$ & $73,79 \pm 1,17$ & $72,43 \pm 3,15$ \\
\hline $400 \mathrm{ppb}$ & $74,95 \pm 0,68$ & $74,58 \pm 2,33$ & $72,79 \pm 1,17$ & $74,11 \pm 1,68$ \\
\hline Rerata & $73,01 \pm 2,65$ & $73,26 \pm 2,67$ & $72,99 \pm 1,46$ & \\
\hline
\end{tabular}


dengan pakan yang masuk ke dalam tubuh ayam. Bobot relatif karkas pada penelitian ini berbeda dengan penelitian Utami (2009), di mana pemberian AFB1 pada level 1500 ppb mampu menurunkan bobot karkas sebesar $9,72-23,41 \%$. Dalam penelitian ini, diduga paparan AFB1 400 ppb yang diberikan masih dapat ditoleransi oleh ayam dan kemampuan ayam dalam beradaptasi dengan baik, sehingga pemberian penambahan $\mathrm{M}+\mathrm{C}$ pada pakan menyebabkan kondisi karkas dalam penelitian ini tergolong normal. Kemampuan adaptasi ayam dengan peningkatan konsumsi pakan menyebabkan meningkat pula konsumsi $\mathrm{M}+\mathrm{C}$-nya (Purnamasari, et. al., 2019) sehingga kandungan AFB1 yang terkandung dalam pakan mampu diminimalkan melalui reaksi konjugasi glutation di dalam organ hati. Pemberian AFB1 maupun $\mathrm{M}+\mathrm{C}$ tidak berpengaruh terhadap pembentukan daging dan karkas pada penelitian ini. Ayam masih dapat beradaptasi dengan pemberian AFB1 dengan dosis tertinggi $400 \mathrm{ppb}$ dan level $\mathrm{M}+\mathrm{C}$ yang tinggi (125\%) maupun rendah (75\%).

Pengukuran mortalitas dilakukan dengan mencatat kejadian kematian setiap hari. Gambar 2 merupakan grafik kejadian kematian pada ayam selama penelitian yang tersaji dalam persentase mortalitas.

Urutan kejadian kematian di atas 5\% tertinggi hingga terendah dialami pada ayam dengan perlakuan T3 kemudian diikuti oleh perlakuan T2 selanjutnya perlakuan T5. Kejadian kematian kurang dari 5\% persen tertinggi pada perlakuan T1 kemudian T6 dan T9 dan perlakuan dengan kematian $0 \%$ yaitu perlakuan T4, T7, dan T8. Tingginya kematian pada perlakuan T3 (0 ppb dan $\mathrm{M}+\mathrm{C} \quad 125 \%$ ) diduga karena ayam mengalami hyperhomcysteinmia, yaitu suatu penyakit yang disebabkan oleh kelebihan asam amino metionin yang tinggi dalam tubuh. Tingginya kematian bukan disebabkan oleh aflatoksin yang terdapat dalam pakan.. Dugaan tersebut diperkuat dengan tingginya kandungan SGOT darah ayam pada perlakuan T2 dan T3 yang tersaji pada Tabel 12. Monson et al. (2015) menyatakan efek aflatoksikosis pada hewan bervariasi. Kalkun dan itik Anas platyrhynchos lebih sensitif terhadap efek toksik secara akut dan kronik sedangkan ayam lebih resisten terhadap akut aflatoksikosin dibandingkan dengan jenis unggas yang lain. Pada penelitian Yunianta (2013), ayam yang terkena paparan AFB1 sebesar 500 dan 1000 ppb masih mampu bertahan hidup selama 35 hari.

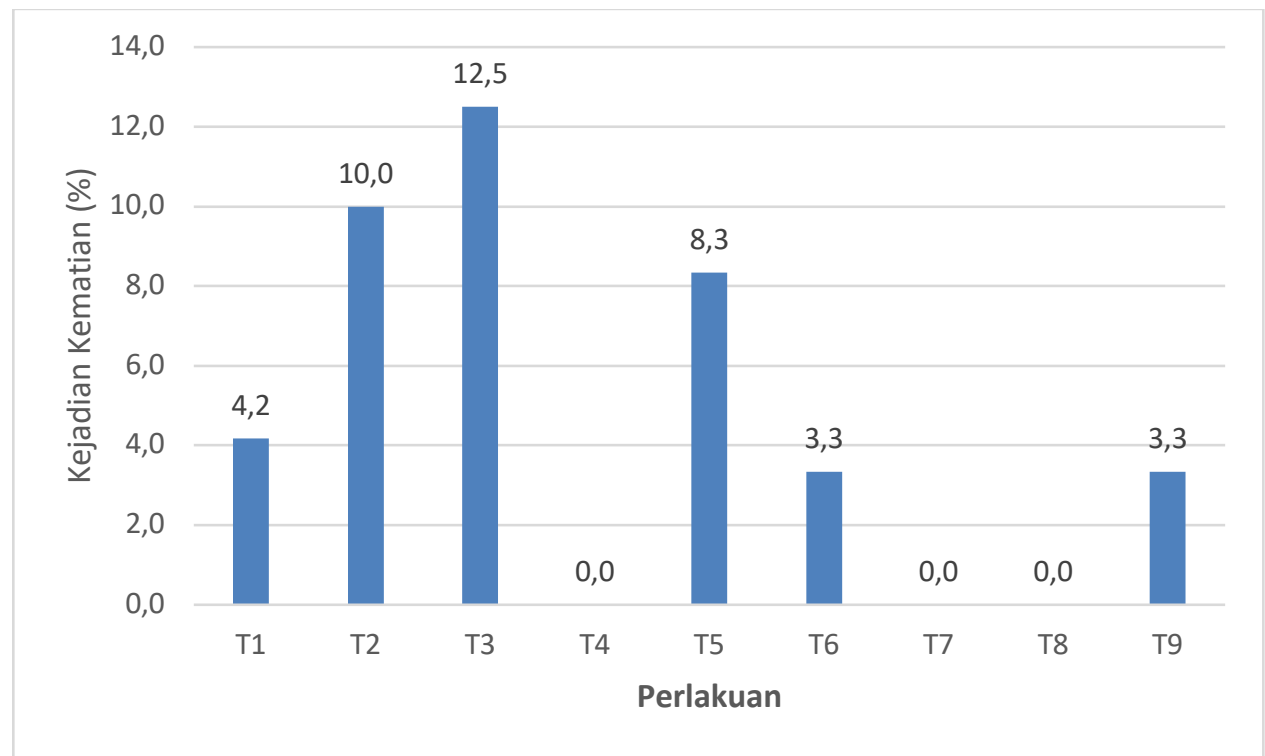

Gambar 2. Grafik persentase kejadian kematian selama penelitian. 
Mortalitas pada penelitian ini tidak menunjukkan pengaruh dari interaksi antara $\mathrm{M}+\mathrm{C}$ dengan AFB1 maupun dari AFB1 saja. Dugaan kematian disebabkan karena paparan $\mathrm{M}+\mathrm{C}$ melebihi normal (125\%) dalam waktu yang lama. Pemberian $\mathrm{M}+\mathrm{C}$ $125 \%$ yang tidak diimbangi dengan konjugasi terhadap AFB1 seperti pada perlakuan T2 dan T3 dengan kandungan AFB1 0 ppb menyebabkan adanya penumpukan homosistein di dalam tubuh ternak. Homosistein adalah asam amino yang mengandung sulfur, yang merupakan produk dimetilasi metionin. Homosistein yang tinggi akan menyebabkan kejadian hyperhomocysteinemia yang menyebabkan kematian (Dewayani, 2007; Oosterbaan et al., 2012). Lain halnya dengan perlakuan $\mathrm{T} 9$ dengan kandungan $\mathrm{M}+\mathrm{C} 125 \%$ dan $\mathrm{AFB} 1$ $400 \mathrm{ppb}$ ayam masih mampu bertahan hidup dan kematian terjadi lebih rendah yaitu 3,33\%.

Paparan aflatoksin selama 3 minggu tidak berpengaruh terhadap mortalitas ayam broiler yang dipelihara, yang menunjukkan kemungkinan adanya daya adaptasi atau toleransi yang kuat terhadap cemaran aflatoksin 400 ppb pada awal pertumbuhan. Hal ini sejalan dengan penelitian Prasetyo dan Susanti (2013), bahwa beberapa spesies unggas seperti itik yang sangat rentan terhadap aflatoksin pada level $<50 \mathrm{ppb}$ masih mampu bertahan terhadap paparan aflatoksin $150 \mathrm{ppb}$ pada awal pertumbuhan.

\section{Hati Ayam}

Parameter lain yang diukur dari organ hati adalah bobot relatif hati ayam. Bobot relatif hati ayam dihitung dengan perbandingan antara bobot hati ayam dengan bobot hidup dikali 100\%. Perhitungan relatif bobot ayam dilakukan karena terdapat perbedaan bobot hidup ayam yang disembelih. Rerata bobot relatif hati tersaji dalam Tabel 4. Hasil analisis pola faktorial menunjukkan bahwa efek interaksi antara $\mathrm{M}+\mathrm{C}$ dengan AFB1 terhadap bobot relatif hati ayam pada penelitian ini tidak signifikan $(\mathrm{P}<0,05)$ pada semua kelompok umur.

Hasil bobot relatif hati ayam tidak menunjukkan adanya perbedaan akibat dari perlakuan kadar $\mathrm{M}+\mathrm{C}$ dan $\mathrm{AFB} 1$, baik pada umur 14 maupun 21 hari. Hal ini diduga terjadi karena hati ayam masih mampu beradaptasi dan mampu mengonjugasi AFB1 dengan bantuan $\mathrm{M}+\mathrm{C}$ yang terkonsumsi melalui pakan, sehingga bobot hati tidak mengalami peningkatan. Ayam mampu beradaptasi dengan baik dengan paparan aflatoksin hingga $400 \mathrm{ppb}$.

Hasil penelitian berbeda dengan penelitian Patriana dan Pribadi (1996), ayam broiler yang diberi aflatoksin 150, 250 dan $350 \mathrm{ppb}$ mengalami peningkatan bobot relatif hati yang berbeda terhadap tingkat pemberian aflatoksin. Meningkatnya bobot hati dapat terjadi ketika AFB1 yang telah dikonsumsi dicerna dalam usus halus kemudian di alirkan oleh pembuluh darah menuju ke hati (Biomin, 2009). Hati merupakan organ target untuk detoksifikasi AFB1 (Widiastuti, 2014). Keracunan AFB1 dengan konsentrasi tinggi mengakibatkan sitokrom sel-sel hepatik beraktifitas sangat tinggi sehingga terjadi proses pembesaran hati (Iwaki et al., 1990) dan efek aflatoksikosis juga menyebabkan warna hati menjadi kuning pucat (Purnamasari et. al., 2019) yang disebabkan karena perlemakan hati (Devegowda dan Murthy, 2005).

Tabel 4. Bobot relatif hati pada umur 14 dan 21 hari (\%)

\begin{tabular}{|c|c|c|c|c|}
\hline \multirow{2}{*}{ AFB1 } & \multicolumn{4}{|c|}{$\mathrm{M}+\mathrm{C}$} \\
\hline & $75 \%$ & $100 \%$ & $125 \%$ & Rerata \\
\hline \multicolumn{5}{|l|}{ Umur 14 hari } \\
\hline $0 \mathrm{ppb}$ & $3,77 \pm 0,69$ & $3,53 \pm 0,18$ & $3,15 \pm 0,37$ & $3,48 \pm 0,48$ \\
\hline $200 \mathrm{ppb}$ & $3,62 \pm 0,30$ & $3,69 \pm 0,15$ & $3,25 \pm 0,13$ & $3,52 \pm 0,27$ \\
\hline $400 \mathrm{ppb}$ & $3,05 \pm 0,47$ & $3,25 \pm 0,27$ & $3,45 \pm 0,20$ & $3,25 \pm 0,34$ \\
\hline Rerata & $3,48 \pm 0,55$ & $3,49 \pm 0,26$ & $3,28 \pm 0,26$ & \\
\hline \multicolumn{5}{|l|}{ Umur 21 hari } \\
\hline $0 \mathrm{ppb}$ & $2,77 \pm 0,17$ & $3,09 \pm 0,23$ & $2,82 \pm 0,25$ & $2,89 \pm 0,24$ \\
\hline $200 \mathrm{ppb}$ & $3,06 \pm 0,26$ & $2,84 \pm 0,91$ & $2,82 \pm 0,07$ & $2,91 \pm 0,18$ \\
\hline $400 \mathrm{ppb}$ & $2,70 \pm 0,05$ & $3,28 \pm 0,64$ & $2,68 \pm 0,27$ & $2,88 \pm 0,46$ \\
\hline Rerata & $2,84 \pm 0,23$ & $3,07 \pm 0,39$ & $2,77 \pm 0,20$ & \\
\hline
\end{tabular}




\section{Bursa Fabrisius}

Rata-rata interaksi AFB1 dan level metionin-sistin terhadap bobot bursa fabrisius dapat diihat pada Tabel 5. Hasil analisis pola faktorial menunjukkan bahwa efek interaksi antara $\mathrm{M}+\mathrm{C}$ dengan $\mathrm{AFB} 1$ terhadap bobot relatif bursa fabrisius ayam pada penelitian ini tidak signifikan baik pada umur 14 maupun 21 hari.

Tabel 5 menunjukkan bahwa tidak adanya respons perlakuan $\mathrm{M}+\mathrm{C}$ dan $\mathrm{AFB} 1$ terhadap bobot bursa fabrisius dalam penelitian ini. Sesuai dengan penelitian Susanto (2014), bahwa organ bursa fabrisius tidak mengalami penambahan berat organ yang diakibatkan pemberian dari AFB1 sebesar $2 \mathrm{mg} / \mathrm{kg}$ pada pakannya. Organ bursa fabrisius tidak berkait langsung dengan detoksifikasi AFB1 karena aflatoksin bukan dikenali sebagai antigen oleh tubuh ternak dan tidak terjadi pembentukan antibodi terhadap AFB1 yang harus melibatkan sistem kekebalan yakni limpa, bursa fabrisius dan timus (Susanto, 2014).

Hasil yang diperoleh berbeda dengan penelitian Utami (2009) dan Yunianta (2013), yang melaporkan bahwa perlakuan penambahan AFB1 500- 1500 ppb dalam pakan dapat menurunkan bobot bursa fabrisius dimulai pada hari ke-21. Bursa fabrisius memiliki tanggung jawab terhadap imunitas humoral dan seluler. Aflatoksin B1 menyebabkan hipoplasia pada sistem limfatik, diantaranya bursa fabrisius dan jaringan limfosit sehingga bursa fabrisius mengecil (Quist et al., 2000). Ayam yang digunakan dalam penelitian telah dilakukan vaksin saat berumur satu hari (DOC). Perbedaan hasil penelitian ini apabila dibandingkan dengan penelitian lainnya dapat disebabkan pada penelitian ini ayam yang dipelihara telah diinjeksikan vaksin infectious bursal disease (IBD), sehingga perkembangan dalam bursa fabrisius tidak tampak dan tidak menunjukkan respon dari $\mathrm{M}+\mathrm{C}$ maupun AFB1. Vaksin IBD diberikan untuk mencegah penyakit gumboro yang bersifat imunosupresif. Pemberian vaksin akan berdampak terhadap fisiologi dan fungsi organ limfoid primer terutama bursa fabrisius yang tidak mengalami kerusakan (Zulfikar, 2014).

\section{Kesimpulan}

Dari hasil penelitian ini dapat disimpulkan bahwa kombinasi pemberian asam amino metionin-sistin sebesar 75, 100, dan 125\% serta AFB1 0, 200 dan 400 ppb yang dikonsumsi ayam broiler, belum mampu memperbaiki kinerja produksi organ dalam ayam broiler. Mortalitas tertinggi terjadi pada perlakuan T3 $(\mathrm{M}+\mathrm{C} 125 \%$ dan AFB1 0 ppb). Ayam masih dapat beradaptasi dengan pemberian AFB1 dengan dosis tertinggi $400 \mathrm{ppb}$ dan level $\mathrm{M}+\mathrm{C}$ yang tinggi (125\%) maupun rendah (75\%).

Tabel5. Bobot relatif bursa fabrisius pada umur 14 dan 21 hari (\%)

\begin{tabular}{|c|c|c|c|c|}
\hline \multirow{2}{*}{ AFB1 } & \multicolumn{4}{|c|}{$\mathrm{M}+\mathrm{C}$} \\
\hline & $75 \%$ & $100 \%$ & $125 \%$ & Rerata \\
\hline \multicolumn{5}{|l|}{$\begin{array}{l}\text { Umur } 14 \\
\text { hari }\end{array}$} \\
\hline $0 \mathrm{ppb}$ & $0,21 \pm 0,03$ & $0,19 \pm 0,12$ & $0,23 \pm 0,07$ & $0,21 \pm 0,04$ \\
\hline $200 \mathrm{ppb}$ & $0,16 \pm 0,02$ & $0,20 \pm 0,01$ & $0,18 \pm 0,04$ & $0,18 \pm 0,03$ \\
\hline $400 \mathrm{ppb}$ & $0,17 \pm 0,02$ & $0,21 \pm 0,03$ & $0,20 \pm 0,07$ & $0,19 \pm 0,04$ \\
\hline $\begin{array}{l}\text { Rerata } \\
\text { Umur } 21 \\
\text { hari }\end{array}$ & $0,18 \pm 0,03$ & $0,20 \pm 0,02$ & $0,21 \pm 0,06$ & \\
\hline $0 \mathrm{ppb}$ & $0,27 \pm 0,08$ & $0,25 \pm 0,02$ & $0,21 \pm 0,07$ & $0,24 \pm 0,06$ \\
\hline $200 \mathrm{ppb}$ & $0,25 \pm 0,03$ & $0,24 \pm 0,03$ & $0,29 \pm 0,08$ & $0,26 \pm 0,05$ \\
\hline $400 \mathrm{ppb}$ & $0,32 \pm 0,01$ & $0,22 \pm 0,06$ & $0,19 \pm 0,06$ & $0,24 \pm 0,07$ \\
\hline Rerata & $0,28 \pm 0,05$ & $0,24 \pm 0,04$ & $0,23 \pm 0,08$ & \\
\hline
\end{tabular}




\section{Daftar Pustaka}

Badan Pusat Statistik. (2015). Statistik Indonesia.

https://www.bps.go.id/publication/2 015/08/12/5933145e1d037f5148a6

7bac/statistik-indonesia-2015.html, diakses 18 Februari 2015.

Biomin. (2009). Mycotoxins affetct everyone.

http://www.mycotoxins.info/myco info/science.html, diakses tanggal 18 Februari 2015.

Devegowda, G. \& Murthy T. N. K. (2005). Mycotoxins : Their Effect in Poultry and Some Practical Solution. In The Mycotoxin Blue Book. Edited by D. E. Diaz. Nottingham, University Press.

Dewayani, R. (2007). Penyakit jantung koroner pada "chronic kidney disease". J. Kardiol. Ind. 28: 387 395.

https://doi.org/10.30701/ijc.v28i5.2 25

Iwaki, M., Kitagawa T., Akamatsu Y. \& Aibara K.. (1990). Cytotoxic effect of aflatoxin B1 and its association with cellular components in chicken embryo primary cultured cells. Biochimia et Biophisica. General Subject. 1035 (2):146 - 153. https://doi.org/10.1016/03044165(90)90109-A

Lesson, S. \& J. D. Summers. (2005). Nutrition of The Chicken. 3th Ed. Ontario. Canada. University books.

Monson, M. S., Roger A. C. \& Kent M. R. (2015). Aflatoxicosis: Lessons from toxicity and responses to aflatoxin B1 in poultry. J. Agri. 5: $742-777$. https://doi.org/10.3390/agriculture5 030742

Oosterbaan, A. M., Steegers E. A. P., \& Ursem N. T. C. (2012). The effect of homocysteine and folic acid on angiogenesis and VEGF expression during chicken vascular development. Microvasc. Res. 83. 98 104. https://doi.org/10.1016/j.mvr.2011. 11.001.

Patriana, U. \& Pribadi E. S. (1996). Studi mengenai sifat akumulasi aflatoksin pada organ jeroan ayam yang mendapatkan suntikan kortikosteroid dan antibiotik. Med. Vet. $3(1): 43-52$. http://repository.ipb.ac.id/handle/12 3456789/24804

Prasetyo, L. H. \& Susanti. T. (2010). Pengaruh genotipa dan kadar aflatoksin dalam ransum pada karakteristik awal bertelur itik lokal. J. Anim. Vet. Sci. 15(3): $215-219$. https://www.researchgate.net/public ation/265999515

Purnamasari L., Agus A \& Noviandi CT. (2016). Kajian Produksi Aflatoksin B1 Kasar Dari Isolat Kapang Aspergillus flavus Lokal Pada Media Jagung Dan Jagung+Kacang Tanah. Buletin Peternakan 40 (2): 133-137

https://doi.org/10.21059/buletinpete rnak.v40i2.9354

Purnamasari L., Agus A \& Noviandi CT. (2019). Effects of MethionineCysteine Amino Acid Supplementations in the Aflatoxin B1 Contaminated Diet on Broiler Production Performance. Buletin Peternakan 43 (4): 231 - 236. https://doi.org/10.21059/buletinpete rnak.v43i4.31150

Purnamasari L., Agus A \& Noviandi CT. (2019). Physiological Response on Broiler Chicken's Liver Supplemented Amino Acid Metionine-Cystine in Feed Contaminated with Aflatoxin B1. Journal of Livestock Science and Production. 3 (1) : 136 - 147. http://dx.doi.org/10.31002/jalspro.v 3i1.1375

Quist, C. F., Bounous D. I.,. Killburn J. V, Nettles V. F. \& Wyatt R. D.. (2000). The effect of dietary aflatoxin on wild turkey poults. J. Wildlife Disease 36: 436 - 444. http://dx.doi.org/10.7589/00903558-36.3.436

Sadeghi, A.A., Saei M.M \& Ahmadvand H. 2014. The efficacy of dietary savory essential oil on reducing the toxicity of Aflatoxin B1 in broiler chicks. Kafkas Univ Vet Fak Derg 20(4) : 
481 486

https://doi.org/109775/kvfd.2013.1 0217

Standar Nasional Indonesia. (1998). Jagung Sebagai Bahan Baku Pakan 014483-1998. Jakarta, Indonesia.

Statistik Peternakan dan Kesehatan Hewan. (2015). Statistik Peternakan dan Kesehatan Hewan. Direktorat Jenderal Peternakan dan Kesehatan Hewan. Jakarta, Indonesia.

Susanto, A. 2014. Glukomanan dari iles-iles (Amorphopalus ancophylus) sebagai pengikat aflatoksin pada pakan ayam broiler. (Disertasi). Institut Pertanian Bogor Indonesia.

Utami, M. M. D., (2009). Efektivitas Ekstrak Bawang Putih dalam Pakan untuk Detoksifikasi Aflatoksin B1 pada Ayam Broiler. (Tesis). Universitas Gadjah Mada Indonesia.
Widiastuti, R. (2014). Residu aflatoksin dan metabolitnya pada berbagai produk pangan asal hewan dan pencegahannya. Wartazoa 24 (3): 179 190. http://dx.doi.org/10.14334/wartazoa .v24i4.1089

Yunianta. (2013). Upaya Penurunan Tingkat Toksisitas Aflatoksin B1 pada Jagung serta Penggunaannya Sebagai Pakan Broiler. (Tesis). Universitas Gadjah Mada Indonesia.

Zulfikar. (2014). Manajemen Pemeliharaan Ayam Petelur Ras. Fakultas Pertanian. Universitas Syiah Kuala. Aceh. 